\title{
SAFETY EVALUATION OF RURAL DRINKING WATER SOURCES IN NANG COUNTY, TIBET AUTONOMOUS REGION OF CHINA
}

\author{
ZONG, Y. C. $.^{1,2,3,4,5,6}-$ HUANG, D. C. ${ }^{6}-$ DUAN, X. L. $^{6}-$ LU, G. H. ${ }^{1,2,3,4,5,6^{*}}$ \\ ${ }^{1}$ Res. Institute of Tibet Plateau Ecology, Tibet Agriculture \& Animal Husbandry University, \\ Linzhi 860000, China \\ ${ }^{2}$ Tibet Key Laboratory of Forest Ecology in Plateau Area, Ministry of Education, Linzhi \\ 860000, China \\ ${ }^{3}$ National Key Station of Field Scientific Observation \& Experiment, Linzhi 860000, China \\ ${ }^{4}$ Key Laboratory of Forest Ecology in Plateau Area, Tibet Autonomous Region, Linzhi 860000, \\ China \\ ${ }^{5}$ United Key Laboratories of Ecological Security, Tibet Autonomous Region, Linzhi 860000, \\ China \\ ${ }^{6}$ Water Conservancy Project \& Civil Engineering College, Tibet Agriculture \& Animal \\ Husbandry University, Linzhi 860000, China \\ *Corresponding author \\ e-mail: ghlu@hhu.edu.cn; phone: +86-130-6257-7435 \\ (Received $5^{\text {th }}$ Feb 2019; accepted $6^{\text {th }}$ Mar 2019)
}

\begin{abstract}
This paper evaluates the quality of drinking water sources of 9 villages in Nang County, Tibet Autonomous Region (TAR) of China using the water quality index (WQI) model of the Canadian Council of Ministers of the Environment (CCME), and verifies the evaluation results by the comprehensive pollutant index (CPI) method. The results show that CCME WQI and CPI have outputted similar rankings, and the results of the two methods have high Spearman's rank correlation coefficient. This means CCME WQI is a feasible way to evaluate the safety of rural drinking water sources. CCME WQI evaluation shows that the water qualities in the 9 villages satisfy the requirements on drinking water.

Keywords: comprehensive pollution index (CPI), the CCME water quality index (WQI), drinking water safety, water quality protection, Spearman's rank correlation coefficient
\end{abstract}

\section{Introduction}

The hygiene and safety of drinking water directly bears on the health of people. To ensure drinking water safety, it is necessary to implement a whole process control before, during and after consumption. This control strategy relies heavily on the safety evaluation of drinking water. To date, the safety of rural drinking water has been mainly evaluated by analytic hierarchy process (AHP) (Guo et al., 2018; Xu et al., 2016), fuzzy evaluation (Mohamed et al., 2018; Wang et al., 2018), entropy weight method (Li et al., 2018), principal component analysis (PCA) (Naz et al., 2016), Comprehensive Pollution Index (CPI) (Savio et al., 2018), etc. In most studies, only one of these methods is adopted to evaluate the safety of drinking water. However, the evaluation result on the same object may vary from method to method. This problem has not been fully recognized or rationally solved in the existing studies on safety evaluation of rural drinking water. Moreover, there is no report on the safety features or regional differences of drinking water (Hood et al., 2014). 
Currently, Canadian Council of Ministers of the Environment (CCME) water quality index (WQI) (Hurley et al., 2012) is mainly applied in the management of surface water environment, while the comprehensive pollution index (CPI) (Sun et al., 2013) is mainly used to evaluate the drinking water sources. Targeting the quality evaluation of drinking water sources in 9 villages of Nang County, China's Tibet Autonomous Region (TAR), this paper explores the correlation and differences between CCME WQI and CPI, with the aim to assess the applicability of CCME WQI in the evaluation of drinking water sources. Specifically, CCME WQI was adopted to evaluate the safety of drinking water in the 9 villages, and results were verified by CPI method. The evaluation of drinking water safety in these villages can lay a solid basis for decisions on selecting and protecting drinking water sources.

\section{Materials and methods}

Based on the field monitoring data of drinking water in 9 villages of Nang County, TAR, two evaluation models were constructed by CCME WQI and CPI, respectively.

\section{Overview of the study area}

Nang County $\left(28^{\circ} 40^{\prime} \sim 29^{\circ} 29^{\prime} \mathrm{N}\right.$; $\left.92^{\circ} 28^{\prime} \sim 93^{\circ} 31^{\prime} \mathrm{E}\right)$ is a border county southwest of Nyingtri City and southeast of TAR. It covers an area of more than $4,200 \mathrm{~km}^{2}$ on the northern foothills of the Himalayas and in the middle and lower reaches of the Yarlung Tsangpo River. With jurisdiction over 6 townships, the county is home to over 18,000 people living in 51 administrative villages and 1 neighborhood community. Most administrative villages are scarcely populated and scattered in remote areas, making it difficult to implement centralized water supply. Currently, the villagers mainly drink natural surface water, which fluctuates greatly by season due to the low vegetation coverage, and the drinking water sources are far from abundant (Tian et al., 2015). To rationalize the selection of rural drinking water sources, it is imperative to carry out targeted safety evaluation of rural drinking water and adopt rational remediation measures.

\section{Data sources}

As shown in Figure 1, a total of 9 monitoring points were arranged in light of the status of the drinking water sources. The monitoring was carried out in August, 2018. Four sampling points were selected at each monitoring point to measure 16 items, namely, zinc, copper, iron, manganese, total hardness, dissolved oxygen (DO), chemical oxygen demand (COD), total dissolved solids, arsenic, hexavalent chromium, fluoride, anionic synthetic detergent, cyanide, volatile phenols, lead and selenium. These items were selected according to relevant literature (Chang et al., 2017), and analyzed according to the Environmental Quality Standards for Surface Water (GB3838-2002) and the Water and Wastewater Analysis Method.

\section{Analysis methods}

In this paper, CCME WQI is employed to evaluate the drinking water sources at the 9 monitoring points, and CPI was selected to verify the evaluation results of CCME WQI. 


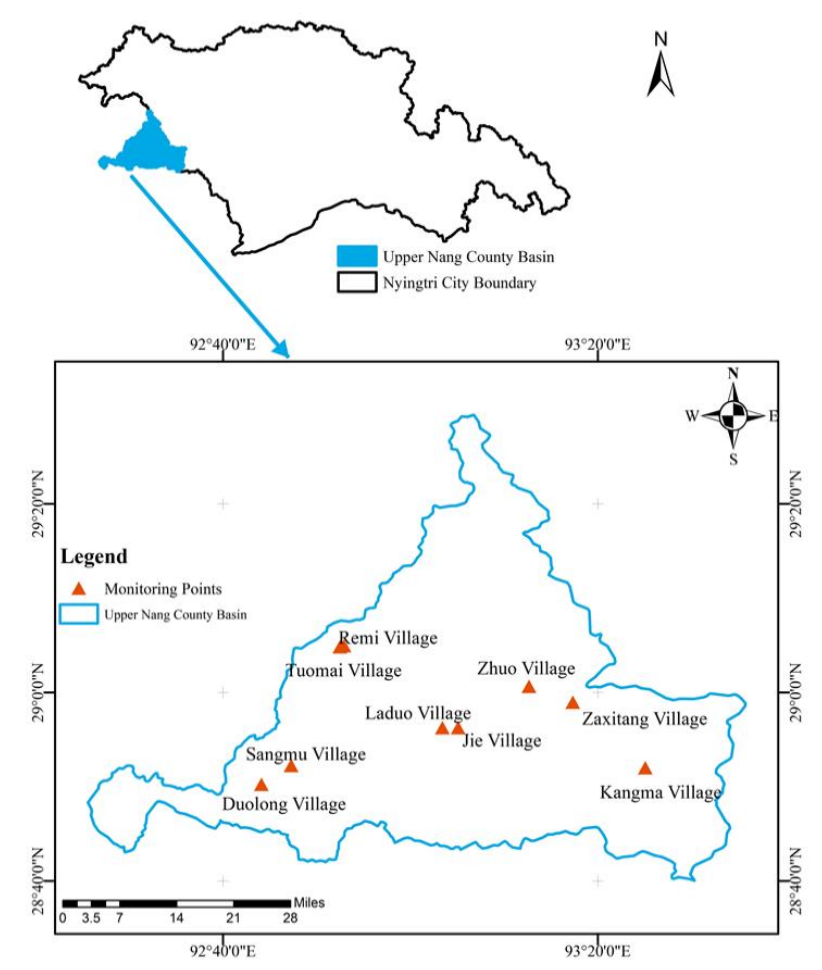

Figure 1. Location map of monitoring points

$C P I$

CPI (Meng et al., 2014), an indicator of the degree of water pollution, is the sum of the relative pollution indices of different pollution items. This method can determine the pollution degree of the water bodies in our research. CPI value can be derived from single pollution indices by the following equations:

$$
\mathrm{P}_{\mathrm{ij}}=\frac{c_{i j}-c_{j o k}}{c_{j o k+1}-c_{j o k}}+P_{j o k}
$$

where $\mathrm{P}_{\mathrm{ij}}$ is the single pollution index of the $\mathrm{j}$-th item of the $\mathrm{i}$-th water sample (the serial number of water sample $i=1,2, \ldots, n$; the serial number of pollution item $j=1,2, \ldots$, $\mathrm{m})$; $c_{\mathrm{ij}}$ is the measured content of the $\mathrm{j}$-th item of the $\mathrm{i}$-th water sample; $\mathrm{c}_{\mathrm{jok}}$ is the standard content of level $\mathrm{k}$ of the $\mathrm{j}$-th item; $c_{\mathrm{jok}+1}$ is the standard content of level $\mathrm{k}+1$ of the $\mathrm{j}$-th item; $P_{\mathrm{jok}}$ is the standard index value of level $\mathrm{k}$ of the $\mathrm{j}$-th item. The $\mathrm{c}_{\mathrm{ij}}$ falls between $c_{\text {jok }}$ and $c_{\text {jok }+1}$.

$$
P_{i}=\frac{1}{\mathrm{~m}} \sum_{\mathrm{i}=1}^{\mathrm{m}} P_{i \mathrm{j}}
$$

where $P_{i}$ is CPI of the $i$-th water sample; $m$ is the total number of pollution items.

\section{CCME WQI}

CCME WQI is a water quality management tool that evaluates the water quality of the target water body against three aspects: the number of terms whose objectives are 
not met (Scope), the frequency with which the objectives are not met (Frequency) and the amount by which the objectives are not met (Amplitude). This method has been highly lauded for its flexibility in parameter selection and study area, intuitiveness in computing process and evaluation results, and tolerance of the missing values.

(1) Scope $F_{1}$

The percentage of items that do not meet their objectives during the evaluation period, relative to the total number of evaluation items of the $i$-th sampling point $F_{1 i}$ can be expressed as:

$$
\mathrm{F}_{1 \mathrm{i}}=\frac{\mathrm{m}}{\mathrm{M}} \times 100
$$

where $\mathrm{M}$ is the total number of evaluation items of each sampling point in the evaluation period; $\mathrm{N}$ is the number of sampling points; $\mathrm{m}$ is the number of items failing to meet the objectives of water quality.

(2) Frequency $F_{2}$

The percentage of individual monitoring of the i-th sampling point that does not meet objectives $\mathrm{F}_{2 \mathrm{i}}$ can be expressed as:

$$
\mathrm{F}_{2 \mathrm{i}}=\frac{\mathrm{q}}{\mathrm{M} \times \mathrm{p}} \times 100
$$

where $\mathrm{p}$ is the number of times by which each item of a sampling point is monitored; $\mathrm{q}$ is the number of times by which a sampling point fails to meet the objectives of water quality.

(3) Amplitude $\mathrm{F}_{3}$

Let $\mathrm{C}_{\mathrm{j}}$ be the objective of water quality for the $\mathrm{j}$-th item and $a_{\mathrm{ij}}$ be the monitored value of the $j$-th item of the $i$-th sampling point. Then, the amount by which failed items do not meet their objectives $\mathrm{e}_{\mathrm{ij}}$ can be calculated as follows:

For items that must exceed the objective (e.g. DO), the amplitude $\mathrm{e}_{\mathrm{ij}}$ can be calculated as:

$$
\mathrm{e}_{\mathrm{i} j}=\left\{\begin{array}{c}
\frac{C_{j}}{a_{\mathrm{i} j}}-1 a_{\mathrm{i} j}<C_{j} \\
0 a_{\mathrm{i} j} \geq C_{j}
\end{array}\right.
$$

For items that must not exceed the objective (e.g. total hardness and COD), the amplitude $\mathrm{e}_{\mathrm{ij}}$ can be calculated as:

$$
\mathrm{e}_{\mathrm{i} j}=\left\{\begin{array}{c}
\frac{a_{\mathrm{i} j}}{C_{j}}-1 a_{\mathrm{ij}}>C_{j} \\
0 a_{\mathrm{i} j} \leq C_{j}
\end{array}\right.
$$

(4) Level classification

CCME WQI is defined in the interval $[0,100]$. The greater the value of CCME WQI, the better the evaluation result. CCME WQI can be calculated as:

$$
\text { CCME WQI }=100-\frac{\sqrt{F_{1}^{2}+F_{2}^{2}+F_{3}^{2}}}{1.732}
$$


According to the value of CCME WQI, the quality of the target water bodies was divided into 5 levels (Alazawii et al., 2018; Feng et al., 2018) (Table 1).

Table 1. Five levels of water quality

\begin{tabular}{c|c}
\hline Level & The value of the CCME WQI \\
\hline Excellent & {$[94,100]$} \\
Good & {$[79,94)$} \\
Fair & {$[64,79)$} \\
Marginal & {$[44,64)$} \\
Poor & {$[0,44)$} \\
\hline
\end{tabular}

\section{Results and discussion}

\section{Monitoring data and water quality objectives}

As mentioned before, 16 water quality items, namely, zinc, copper, iron, manganese, total hardness, DO, COD, total dissolved solids, arsenic, hexavalent chromium, fluoride, anionic synthetic detergent, cyanide, volatile phenols, lead and selenium, were measured at the four sampling points of each monitoring point. The measured value of each item is recorded in Table 2.

Table 2. Measured value of each item

\begin{tabular}{|c|c|c|c|c|c|c|c|c|c|c|}
\hline Item & Station & $\begin{array}{l}\text { Tuomai } \\
\text { Village }\end{array}$ & $\begin{array}{l}\text { Zhuo } \\
\text { Village }\end{array}$ & $\begin{array}{c}\text { Zaxitang } \\
\text { Village }\end{array}$ & $\begin{array}{l}\text { Remi } \\
\text { Village }\end{array}$ & $\begin{array}{c}\text { Sangmu } \\
\text { Village }\end{array}$ & $\begin{array}{l}\text { Duolong } \\
\text { Village }\end{array}$ & $\begin{array}{l}\text { Laduo } \\
\text { Village }\end{array}$ & $\begin{array}{c}\text { Jie } \\
\text { Village }\end{array}$ & $\begin{array}{c}\text { Kangma } \\
\text { Village }\end{array}$ \\
\hline \multirow{4}{*}{$\begin{array}{l}\text { Zinc } \\
(\mathrm{mg} / \mathrm{L})\end{array}$} & 1 & 0.13 & 0.09 & 0.12 & 0.06 & 0.07 & 0.09 & 0.06 & 0.08 & 0.09 \\
\hline & 2 & 0.14 & 0.11 & 0.13 & 0.07 & 0.08 & 0.11 & 0.09 & 0.09 & 0.1 \\
\hline & 3 & 0.15 & 0.1 & 0.13 & 0.06 & 0.09 & 0.12 & 0.11 & 0.09 & 0.11 \\
\hline & 4 & 0.08 & 0.08 & 0.13 & 0.07 & 0.08 & 0.07 & 0.07 & 0.08 & 0.08 \\
\hline \multirow{4}{*}{$\begin{array}{l}\text { Copper } \\
(\mathrm{mg} / \mathrm{L})\end{array}$} & 1 & 0.008 & 0.007 & 0.15 & 0.009 & 0.011 & 0.012 & 0.012 & 0.014 & 0.01 \\
\hline & 2 & 0.01 & 0.009 & 0.17 & 0.011 & 0.013 & 0.014 & 0.012 & 0.015 & 0.012 \\
\hline & 3 & 0.009 & 0.007 & 0.13 & 0.013 & 0.014 & 0.014 & 0.014 & 0.013 & 0.016 \\
\hline & 4 & 0.007 & 0.007 & 0.11 & 0.007 & 0.008 & 0.006 & 0.006 & 0.008 & 0.008 \\
\hline \multirow{4}{*}{$\begin{array}{l}\text { Iron } \\
(\mathrm{mg} / \mathrm{L})\end{array}$} & 1 & 0.015 & 0.015 & 0.015 & 0.015 & 0.015 & 0.015 & 0.015 & 0.015 & 0.015 \\
\hline & 2 & 0.019 & 0.02 & 0.019 & 0.019 & 0.019 & 0.018 & 0.019 & 0.02 & 0.018 \\
\hline & 3 & 0.02 & 0.021 & 0.017 & 0.019 & 0.021 & 0.016 & 0.016 & 0.021 & 0.019 \\
\hline & 4 & 0.015 & 0.015 & 0.015 & 0.015 & 0.015 & 0.015 & 0.015 & 0.015 & 0.015 \\
\hline \multirow{4}{*}{$\begin{array}{c}\text { Manganese } \\
(\mathrm{mg} / \mathrm{L})\end{array}$} & 1 & 0.005 & 0.005 & 0.005 & 0.005 & 0.005 & 0.005 & 0.005 & 0.005 & 0.005 \\
\hline & 2 & 0.006 & 0.007 & 0.007 & 0.007 & 0.005 & 0.007 & 0.006 & 0.008 & 0.005 \\
\hline & 3 & 0.007 & 0.008 & 0.008 & 0.008 & 0.006 & 0.008 & 0.007 & 0.009 & 0.006 \\
\hline & 4 & 0.005 & 0.005 & 0.005 & 0.005 & 0.005 & 0.005 & 0.005 & 0.005 & 0.005 \\
\hline \multirow{4}{*}{$\begin{array}{c}\mathrm{Ca}^{2+} \\
(\mathrm{mg} / \mathrm{L})\end{array}$} & 1 & 87 & 176 & 165 & 179 & 254 & 287 & 247 & 219 & 143 \\
\hline & 2 & 489 & 470 & 562 & 570 & 555 & 586 & 544 & 511 & 441 \\
\hline & 3 & 501 & 486 & 558 & 582 & 598 & 592 & 536 & 523 & 445 \\
\hline & 4 & 125 & 189 & 199 & 198 & 264 & 278 & 248 & 236 & 148 \\
\hline \multirow{4}{*}{$\begin{array}{c}\mathrm{DO} \\
(\mathrm{mg} / \mathrm{L})\end{array}$} & 1 & 7.96 & 8.03 & 8.06 & 8.11 & 8.12 & 7.85 & 8.06 & 8.02 & 8.05 \\
\hline & 2 & 7.67 & 8.16 & 8.25 & 8.02 & 8.13 & 7.95 & 8.22 & 8.35 & 8.65 \\
\hline & 3 & 7.89 & 8.21 & 8.26 & 8.12 & 8.28 & 8.25 & 8.65 & 8.37 & 8.45 \\
\hline & 4 & 7.85 & 8.09 & 8 & 8.25 & 8.36 & 7.68 & 8.15 & 8.26 & 8.16 \\
\hline \multirow{4}{*}{$\begin{array}{l}\text { COD } \\
(\mathrm{mg} / \mathrm{L})\end{array}$} & 1 & 1.35 & 1.36 & 1.41 & 1.25 & 1.75 & 1.95 & 2.02 & 1.58 & 1.61 \\
\hline & 2 & 3.46 & 5.62 & 4.54 & 5.64 & 5.1 & 5.01 & 5.12 & 4.55 & 4.88 \\
\hline & 3 & 6.23 & 6.25 & 5.23 & 6.25 & 5.28 & 5.38 & 5.31 & 5.26 & 5.14 \\
\hline & 4 & 3.25 & 2.36 & 3.15 & 2.25 & 4.21 & 2.01 & 2.68 & 3.68 & 3.26 \\
\hline
\end{tabular}




\begin{tabular}{|c|c|c|c|c|c|c|c|c|c|c|}
\hline \multirow{4}{*}{$\begin{array}{l}\text { Solid solubility } \\
\text { (mg/L) }\end{array}$} & 1 & 227 & 178 & 223 & 185 & 265 & 198 & 213 & 231 & 176 \\
\hline & 2 & 745 & 741 & 358 & 536 & 654 & 464 & 456 & 485 & 458 \\
\hline & 3 & 689 & 685 & 485 & 562 & 689 & 498 & 495 & 489 & 487 \\
\hline & 4 & 326 & 215 & 256 & 167 & 245 & 138 & 235 & 312 & 259 \\
\hline \multirow{4}{*}{$\begin{array}{l}\text { Arsenic } \\
(\mathrm{mg} / \mathrm{L})\end{array}$} & 1 & 0.005 & 0.005 & 0.005 & 0.005 & 0.005 & 0.005 & 0.005 & 0.005 & 0.005 \\
\hline & 2 & 0.005 & 0.005 & 0.005 & 0.005 & 0.005 & 0.005 & 0.005 & 0.005 & 0.005 \\
\hline & 3 & 0.005 & 0.005 & 0.005 & 0.005 & 0.005 & 0.005 & 0.005 & 0.005 & 0.005 \\
\hline & 4 & 0.005 & 0.005 & 0.005 & 0.005 & 0.005 & 0.005 & 0.005 & 0.005 & 0.005 \\
\hline \multirow{4}{*}{$\begin{array}{l}\text { Hexavalent } \\
\text { chromium } \\
(\mathrm{mg} / \mathrm{L})\end{array}$} & 1 & 0.002 & 0.002 & 0.002 & 0.002 & 0.002 & 0.002 & 0.002 & 0.002 & 0.002 \\
\hline & 2 & 0.002 & 0.002 & 0.002 & 0.002 & 0.002 & 0.002 & 0.002 & 0.002 & 0.002 \\
\hline & 3 & 0.002 & 0.002 & 0.002 & 0.002 & 0.002 & 0.002 & 0.002 & 0.002 & 0.002 \\
\hline & 4 & 0.002 & 0.002 & 0.002 & 0.002 & 0.002 & 0.002 & 0.002 & 0.002 & 0.002 \\
\hline \multirow{4}{*}{$\begin{array}{l}\text { Fluoride } \\
\text { (mg/L) }\end{array}$} & 1 & 0.5 & 0.45 & 0.3 & 0.7 & 0.6 & 0.5 & 0.5 & 0.3 & 0.4 \\
\hline & 2 & 0.8 & 0.9 & 0.8 & 1 & 1.1 & 0.8 & 0.8 & 0.8 & 0.8 \\
\hline & 3 & 0.9 & 0.8 & 0.9 & 1.1 & 1.1 & 0.9 & 0.8 & 0.9 & 0.8 \\
\hline & 4 & 0.6 & 0.5 & 0.6 & 0.6 & 0.5 & 0.6 & 0.5 & 0.4 & 0.4 \\
\hline \multirow{4}{*}{$\begin{array}{l}\text { Anionic synthetic } \\
\text { detergent } \\
(\mathrm{mg} / \mathrm{L})\end{array}$} & 1 & 0.025 & 0.025 & 0.025 & 0.025 & 0.025 & 0.025 & 0.025 & 0.025 & 0.025 \\
\hline & 2 & 0.025 & 0.025 & 0.025 & 0.025 & 0.025 & 0.025 & 0.025 & 0.025 & 0.025 \\
\hline & 3 & 0.025 & 0.025 & 0.025 & 0.025 & 0.025 & 0.025 & 0.025 & 0.025 & 0.025 \\
\hline & 4 & 0.025 & 0.025 & 0.025 & 0.025 & 0.025 & 0.025 & 0.025 & 0.025 & 0.025 \\
\hline \multirow{4}{*}{$\begin{array}{c}\text { Cyanide } \\
(\mathrm{mg} / \mathrm{L})\end{array}$} & 1 & 0.001 & 0.001 & 0.001 & 0.001 & 0.001 & 0.001 & 0.001 & 0.001 & 0.001 \\
\hline & 2 & 0.001 & 0.001 & 0.001 & 0.001 & 0.001 & 0.001 & 0.001 & 0.001 & 0.001 \\
\hline & 3 & 0.001 & 0.001 & 0.001 & 0.001 & 0.001 & 0.001 & 0.001 & 0.001 & 0.001 \\
\hline & 4 & 0.001 & 0.001 & 0.001 & 0.001 & 0.001 & 0.001 & 0.001 & 0.001 & 0.001 \\
\hline \multirow{4}{*}{$\begin{array}{l}\text { Volatile phenols } \\
\qquad(\mathrm{mg} / \mathrm{L})\end{array}$} & 1 & 0.001 & 0.001 & 0.001 & 0.001 & 0.001 & 0.001 & 0.001 & 0.001 & 0.001 \\
\hline & 2 & 0.001 & 0.001 & 0.001 & 0.001 & 0.001 & 0.001 & 0.001 & 0.001 & 0.001 \\
\hline & 3 & 0.001 & 0.001 & 0.001 & 0.001 & 0.001 & 0.001 & 0.001 & 0.001 & 0.001 \\
\hline & 4 & 0.001 & 0.001 & 0.001 & 0.001 & 0.001 & 0.001 & 0.001 & 0.001 & 0.001 \\
\hline \multirow{4}{*}{$\begin{array}{l}\text { Lead } \\
(\mathrm{mg} / \mathrm{L})\end{array}$} & 1 & 0.0034 & 0.0054 & 0.0066 & 0.0068 & 0.0065 & 0.0058 & 0.0054 & 0.0067 & 0.0064 \\
\hline & 2 & 0.0036 & 0.0056 & 0.0078 & 0.0048 & 0.0078 & 0.0069 & 0.0075 & 0.0075 & 0.0069 \\
\hline & 3 & 0.0042 & 0.0054 & 0.0067 & 0.0065 & 0.0068 & 0.0078 & 0.0067 & 0.0078 & 0.0072 \\
\hline & 4 & 0.0045 & 0.005 & 0.0056 & 0.0052 & 0.0065 & 0.0048 & 0.0054 & 0.0067 & 0.0053 \\
\hline \multirow{4}{*}{$\begin{array}{l}\text { Selenium } \\
(\mathrm{mg} / \mathrm{L})\end{array}$} & 1 & 0.0025 & 0.0025 & 0.0025 & 0.0025 & 0.0025 & 0.0025 & 0.0025 & 0.0025 & 0.0025 \\
\hline & 2 & 0.0025 & 0.0025 & 0.0025 & 0.0025 & 0.0025 & 0.0025 & 0.0025 & 0.0025 & 0.0025 \\
\hline & 3 & 0.0025 & 0.0025 & 0.0025 & 0.0025 & 0.0025 & 0.0025 & 0.0025 & 0.0025 & 0.0025 \\
\hline & 4 & 0.0025 & 0.0025 & 0.0025 & 0.0025 & 0.0025 & 0.0025 & 0.0025 & 0.0025 & 0.0025 \\
\hline
\end{tabular}

According to the Environmental Quality Standards for Surface Water and the Sanitary Standard for Drinking Water Quality, the objectives of the 16 water quality items were determined (Table 3).

Table 3. Objectives of the 16 water quality items

\begin{tabular}{c|c|c|c|c|c}
\hline Item & Objective & Unit & Item & Objective & Unit \\
\hline Zinc & 1 & $\mathrm{mg} / \mathrm{L}$ & Fluoride & 1 & $\mathrm{mg} / \mathrm{L}$ \\
Copper & 1 & $\mathrm{mg} / \mathrm{L}$ & Anionic synthetic detergent & 0.2 & $\mathrm{mg} / \mathrm{L}$ \\
Iron & 0.3 & $\mathrm{mg} / \mathrm{L}$ & Cyanide & 0.05 & $\mathrm{mg} / \mathrm{L}$ \\
Manganese & 0.1 & $\mathrm{mg} / \mathrm{L}$ & Volatile phenols & 0.002 & $\mathrm{mg} / \mathrm{L}$ \\
Arsenic & 0.05 & $\mathrm{mg} / \mathrm{L}$ & Selenium & 0.01 & $\mathrm{mg} / \mathrm{L}$ \\
Lead & 0.01 & $\mathrm{mg} / \mathrm{L}$ & DO & 5 & $\mathrm{mg} / \mathrm{L}$ \\
Total hardness*(CaCO & $3)$ & 450 & $\mathrm{mg} / \mathrm{L}$ & COD & 4 \\
Hexavalent chromium & 0.05 & $\mathrm{mg} / \mathrm{L}$ & Total dissolved solids* & 1000 & $\mathrm{mg} / \mathrm{L}$ \\
\hline
\end{tabular}

*No objective is specified for the corresponding item in the Environmental Quality Standards for

Surface Water. The objective was thus extracted from the Sanitary Standard for Drinking Water Quality 


\section{CPI evaluation results}

According to the Technical Rules for the Evaluation of the Safety Status of Drinking Water Sources in Urban Areas (2005), two aspects of the water quality of river water sources should be evaluated, namely, the level of general pollutants and the level of toxic pollutants. Specifically, the water quality status index of river and underground water sources $=0.3 \times$ the level of general pollutants $+0.7 \times$ the level of toxic pollutants. The level of general pollutants measures by eight items, including zinc, copper, iron, manganese, total hardness, DO, COD and total dissolved solids (the total hardness and total dissolved solids, which are water quality evaluation items for underground water sources, are treated as those for surface water sources), while the level of toxic pollutants is measured by another eight items, including arsenic, hexavalent chromium, fluoride, anionic synthetic detergent, cyanide, volatile phenols, lead and selenium (the anionic synthetic detergent, which is a water quality evaluation item for underground water source, is treated as one for surface water sources). The specific calculated results are shown in Table 4.

Table 4. CPI evaluation results

\begin{tabular}{c|c|c|c|c}
\hline Monitoring points & Level of general pollutants & Level of toxic pollutants & CPI & Ranking \\
\hline Tuomai Village & 1.193 & 2.700 & 2.248 & 5 \\
Zhuo Village & 1.173 & 2.700 & 2.242 & 3 \\
Zaxitang Village & 1.229 & 2.700 & 2.259 & 7 \\
Remi Village & 1.181 & 3.400 & 2.734 & 8 \\
Sangmu Village & 1.280 & 3.400 & 2.764 & 9 \\
Duolong Village & 1.209 & 2.700 & 2.253 & 6 \\
Laduo Village & 1.184 & 2.400 & 2.035 & 2 \\
Jie Village & 1.187 & 2.700 & 2.246 & 4 \\
Kangma Village & 1.109 & 2.400 & 2.013 & 1 \\
\hline
\end{tabular}

In light of CPI evaluation results in Table 4, the villages in the study area were ranked in descending order by the quality of drinking water source: Kangma Village, Lado Village, Zhuo Village, Jie Village, Tuomai Village, Duolong Village, Zhaxitang Village, Remi Village and Sangmu Village. The water qualities in all villages belong to Level III. On the level of general pollutants, the water quality belongs to Level II; On the elvel of toxic pollutants, the water quality belongs to Level III at 9 monitoring points and Level IV at 2 monitoring points. CPI evaluation results demonstrate that the drinking water sources at 9 monitoring points meet the requirements on Level II water source protection zone for centralized supply of drinking water (Sun et al., 2014; Wang et al., 2017), and can provide drinking water to the local areas. These water sources mainly face high content of toxic pollutants, which should be controlled in future water treatment.

\section{CCME WQI evaluation}

CCME WQI evaluation results of the 9 villages in Nang County were computed according to the equations in the section "Analysis methods - CCME WQI" and recorded in Table 5. 
Table 5. CCME WQI evaluation results

\begin{tabular}{c|c|c|c|c|c|c|c|c|c}
\hline Item & $\begin{array}{c}\text { Tuomai } \\
\text { Village }\end{array}$ & $\begin{array}{c}\text { Zhuo } \\
\text { Village }\end{array}$ & $\begin{array}{c}\text { Zaxitang } \\
\text { Village }\end{array}$ & $\begin{array}{c}\text { Remi } \\
\text { Village }\end{array}$ & $\begin{array}{c}\text { Sangmu } \\
\text { Village }\end{array}$ & $\begin{array}{c}\text { Duolong } \\
\text { Village }\end{array}$ & $\begin{array}{c}\text { Laduo } \\
\text { Village }\end{array}$ & $\begin{array}{c}\text { Jie } \\
\text { Village }\end{array}$ & $\begin{array}{c}\text { Kangma } \\
\text { Village }\end{array}$ \\
\hline $\mathrm{F}_{1}(\%)$ & 12.5 & 12.5 & 12.5 & 18.75 & 18.75 & 12.5 & 12.5 & 12.5 & 6.25 \\
$\mathrm{~F}_{2}(\%)$ & 3.125 & 6.25 & 7.8125 & 9.375 & 10.9375 & 6.25 & 6.25 & 7.8125 & 4.6875 \\
$\mathrm{~F}_{3}(\%)$ & 2.4836 & 3.0841 & 2.3596 & 3.5515 & 3.6032 & 2.7043 & 2.5397 & 2.5265 & 2.1806 \\
$\mathrm{CCME}$ WQI & 91.3967 & 91.7369 & 91.3809 & 87.7241 & 87.2956 & 91.7814 & 91.7989 & 91.3652 & 95.3169 \\
Ranking & 5 & 4 & 6 & 8 & 9 & 3 & 2 & 7 & 1 \\
\hline
\end{tabular}

According to CCME WQI evaluation results, the villages can be ranked in descending order of drinking water source quality as: Kangma Village, Laduo Village, Duolong Village, Zhuo Village, Tuomai Village, Zhaxitang Village, Jie Village, Remi Village and Sangmu Village. Comparing CCME WQIs with Table 1, it can be seen that only one monitoring point belongs to the excellent level, while all the other points belong to the good level. All monitoring points are under limited or no threat, and low or extremely low risk. To sum up, the monitoring points can serve as reliable and safe water sources for centralized supply of drinking water (Venkatramanan et al., 2016).

\section{Results and analysis}

The evaluation results of CPI were compared with those of CCME WQI to find their correlations (Fig. 2).

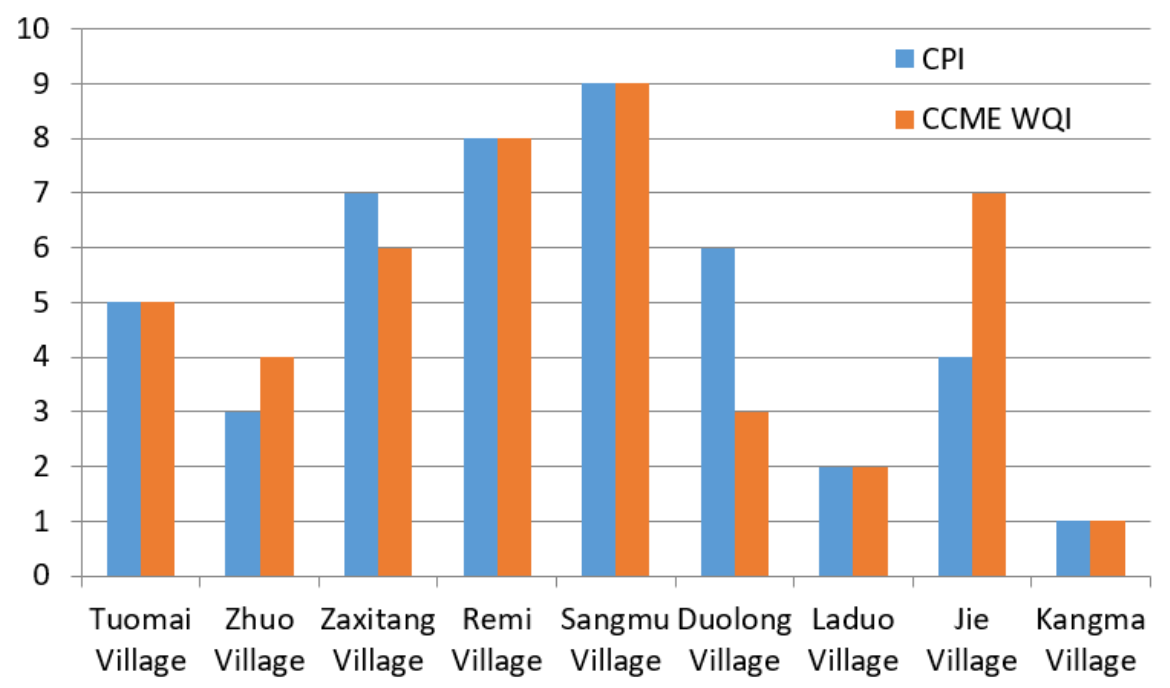

Figure 2. Comparison between evaluation results of CPI and those of CCME WQI

As shown in Figure 2, the water quality ranking of the villages of CCME WQI differs from that of CPI in the following areas: the ranking of two monitoring points (Duolong Village and Jie Village) change by three places; the ranking of no monitoring point change by two places; the ranking of two monitoring points (Zhuo Village and Zhaxitang Village) change by one place; the ranking of the other five monitoring points remains the same. To verify the reliability of CMME WQI method, the research results were tested by the Spearman's rank correlation coefficient. 
The Spearman rank correlation coefficient (Dikbas, 2018) is a nonparametric measure of statistical dependence between two variables. Here, this measure is adopted to check the consistency between the evaluation results of CPI and those of CCME WQI. The calculation formula is as follows:

$$
\mathrm{r}=1-\frac{6 \sum_{i=1}^{n} d_{i}^{2}}{n\left(n^{2}-1\right)}
$$

Where $d_{i}$ is the rank difference of each item; $\mathrm{n}$ is the number of evaluation items. The Spearman's rank correlation coefficient falls in the interval of $[0,1]$. The closer the value is to 1 , the better the correlation.

The Spearman's rank correlation coefficient between the evaluation results of CPI and those of CCME WQI is 0.8333 , revealing a close positive correlation. In other words, the two evaluation methods have outputted highly consistent evaluation results.

The comparison between Tables 4 and 5 shows that CPI and CCME WQI have different emphases in calculation. CPI consists of the level of general pollutants and that of toxic pollutants. The former is about the mean value, while the latter only considers the peak value (without considering the data size or data volume). As a result, the level of toxic pollutants may be exaggerated when a few toxic pollutant items exceed the objectives and differ in the amount by which the objectives are not met, which pushes up the CPI value. The opposite situation will occur when many toxic pollutant items exceed the objectives but agree in the amount by which the objectives are not met.

CCME WQI is made up of three parts: Scope, Frequency and Amplitude. Among them, only the Amplitude is related to the mean value, while the Scope and Frequency are about the number of terms whose objectives are not met and the frequency with which the objectives are not met, respectively. When the mean value does not change much, CCME WQI is negatively correlated with the Scope and Frequency. The opposite situation will occur if only a few terms exceed the objectives and differ in the amount by which the objectives are not met. In summary, CPI and CCME WQI both increase with the growth in the amount by which the objectives are not met and with the reduction of the number of terms failing to meet the objectives. However, the results of the two methods exhibit as the deterioration and improvement of water quality, respectively (Jie Village vs. Zhuo Village). The inverse is also true, as evidenced by Zhaxitang Village vs. Duolong Village.

\section{Conclusions}

This paper evaluates the quality of drinking water sources of 9 villages in the Yarlung Tsangpo River Basin using CCME WQI model, and verifies the evaluation results by CPI method. The subjective weighting of the CPI method may affect the evaluation results, while CCME WQI, free of subjective factors, can output relatively stable results. To ensure the reliability of CCME WQI, the evaluation results were subjected to reliability test by the Spearman's rank correlation coefficient. The following conclusions were drawn from the drinking water source qualities evaluated by CCME WQI.

(1) According to the evaluation results and ranking of monitoring points, CCME WQI and CPI have outputted similar rankings, and the results of the two methods have high Spearman's rank correlation coefficient. This means CCME WQI is a feasible way 
to evaluate the safety of rural drinking water sources. However, CCME WQI also has certain limitations as CPI.

(2) Through CCME WQI evaluation, the 9 villages can be ranked in descending order of drinking water source safety as Kangma Village, Laduo Village, Duolong Village, Zhuo Village, Tuomai Village, Zhaxitang Village, Jie Village, Remi Village and Sangmu Village. Besides, the water qualities at these monitoring points satisfy the requirements on drinking water.

In the future, CCME WQI can be applied to rural drinking water sources after the operation is mature and simplified. And then the safety evaluation of rural drinking water sources will be completed quickly.

Acknowledgements. This work was supported by the Natural Science Foundation of Tibet (NO.XZ 2018 ZR G-20), National Natural Science Foundation of China (NO.51868069,51769034), the Program for Scientific Research Innovation Team in Colleges and Universities of Tibet Autonomous Region.

\section{REFERENCES}

[1] Alazawii, L. H., Nashaat, M. R., Muftin, F. S. (2018): Assessing the effects of al-rasheed electrical power plant on the quality of Tigris River, Southern of Baghdad by Canadian Water Quality Index. - Iraqi Journal of Science 2018(59): 1162-1168.

[2] Chang, C. P., Zheng, N., Zheng, H. P. (2017): Ground water quality evaluation and analyses in Hanzhong City. - Journal of Shaanxi University of Technology (Natural Science Edition) 2017(8): 22-25.

[3] Dikbaş, F. (2018): A new two-dimensional rank correlation coefficient. - Water Resources Management 32(5): 1-15.

[4] Feng, Y., Bao, Q., Cheng, L. L. (2018): Introducing biological indicators into CCME WQI using variable fuzzy set method. - Water Resources Management 32(8): 2901-2915.

[5] Guo, J., Liu, Y., Cheng, X. J., Yan, H., Xu, Y. Q. (2018): A novel prediction model for the degree of rescue safety in mine thermal dynamic disasters based on fuzzy analytical hierarchy process and extreme learning machine. - International Journal of Heat and Technology 36(4): 1336-1342.

[6] Hood, N. E., Turner, L., Colabianchi, N. (2014): Availability of drinking water in US public school cafeterias. - Journal of the Academy of Nutrition \& Dietetics 114(9): 13891395.

[7] Hurley, T., Sadiq, R., Mazumder, A. (2012): Adaptation and evaluation of the Canadian Council of Ministers of the Environment Water Quality Index (CCME WQI) for use as an effective tool to characterize drinking source water quality. - Water Research 46(11): 3544-3552.

[8] Li, Q., Meng, X. X., Liu, Y. B. (2018): Risk assessment of floor water inrush using entropy weight and variation coefficient model. - Geotechnical and Geological Engineering 2018(2): 1-9.

[9] Meng, C. F., Cheng, N. J., Ye, B. X. (2014): Comprehensive pollution in Dex Method was used to evaluate water quality in Jiaozuo and Xinxiang. - Henan Water Resources \& South-to-North Water Diversion 2014(23): 51-52.

[10] Mohamed, A. K., Liu, D., Mohamed, M. A. A. (2018): Groundwater quality assessment of the quaternary unconsolidated sedimentary basin near the Pi river using fuzzy evaluation technique. - Applied Water Science 8(2): 65.

[11] Naz, A., Chowdhury, A., Mishra, B. K. (2016): Metal pollution in water environment and the associated human health risk from drinking water: a case study of Sukinda chromite 
mine. - Human \& Ecological Risk Assessment An International Journal 22(7): 14331455.

[12] Savio, D., Stadler, P., Reischer, G. H. (2018): Opening the black box of spring water microbiology from alpine karst aquifers to support proactive drinking water resource management. - Wiley Interdisciplinary Reviews: Water 2018: e1282.

[13] Sun, T., Zhang, M., Li, M. M. (2014): River water quality evaluation based on correspondence analysis and comprehensive pollution index method. - Environmental Science \& Technology.

[14] Sun, W. H., Jiang, Y. X., Li, X. (2013): Research of the evaluation on heavy-metal pollution in rice by sewage irrigation. - Applied Mechanics \& Materials 295-298: 15941599.

[15] Tian, Y., Yu, C. Q., Luo, K. (2015): Hydrochemical characteristics and element contents of natural waters in Tibet. - Journal of Geography (English Edition) 25(6): 669-686.

[16] Venkatramanan, S., Chung, S. Y., Ramkumar, T. (2016): Assessment of groundwater quality using GIS and CCME WQI techniques: a case study of Thiruthuraipoondi city in Cauvery deltaic region. - Desalination \& Water Treatment 57(26): 12058-12073.

[17] Wang, F., Shui, A. S., Zeng, L. B. (2018): Leak detection method for bottom plate of oil tank based on oil/gas leak detection. - International Journal of Heat and Technology 36(3): 997-1004.

[18] Wang, Y. C., Li, R. J., Wen, S. E. (2017): Assessment of water quality in Shaanxi Section of the Yellow River by a comprehensive pollution index method. - Chinese Journal of Fisheries.

[19] Xu, J., Feng, P., Yang, P. (2016): Research of development strategy on China's rural drinking water supply based on SWOT-TOPSIS method combined with AHP-Entropy: a case in Hebei Province. - Environmental Earth Sciences 75(1): 58. 